\title{
Origin and pathogenesis of antiphospholipid antibodies
}

C.M. Celli ${ }^{1}$ and

A.E. Gharavi ${ }^{2}$

\author{
'Departamento de Bioquímica, Instituto de Química, \\ Universidade de São Paulo, São Paulo, SP, Brasil \\ 2Section of Rheumatology, Department of Medicine, \\ Louisiana State University Medical Center, New Orleans, LA, USA
}

\section{Correspondence \\ C.M. Celli \\ Departamento de Bioquímica Instituto de Química, USP \\ Av. Prof. Lineu Prestes, 748 \\ (Bloco 10T) \\ 05508-900 São Paulo, SP \\ Brasil \\ Fax: 55 (011) 815-5579 \\ E-mail: clmcelli@quim.iq.usp.br/ \\ aghara@pol.net \\ Presented at the XII Annual Meeting of the Federação de Sociedades de Biologia Experimental, Caxambu, MG, Brasil, August 27-30, 1997. \\ Research supported by CNPq and FAPESP.}

Received December 10, 1997 Accepted January 19, 1998

\begin{abstract}
Antiphospholipid antibodies (aPL) are a heterogeneous group of antibodies that are detected in the serum of patients with a variety of conditions, including autoimmune (systemic lupus erythematosus), infectious (syphilis, AIDS) and lymphoproliferative disorders (paraproteinemia, myeloma, lymphocytic leukemias). Thrombosis, thrombocytopenia, recurrent fetal loss and other clinical complications are currently associated with a subgroup of aPL designating the antiphospholipid syndrome. In contrast, aPL from patients with infectious disorders are not associated with any clinical manifestation. These findings led to increased interest in the origin and pathogenesis of aPL. Here we present the clinical features of the antiphospholipid syndrome and review the origin of aPL, the characteristics of experimentally induced aPL and their historical background. Within this context, we discuss the most probable pathogenic mechanisms induced by these antibodies.
\end{abstract}

Key words

- Antiphospholipid antibodies

- Antiphospholipid syndrome

- Systemic lupus erythematosus

- Syphilis

- Cardiolipin

- Beta-2-glycoprotein I

\section{Background}

Antiphospholipid antibodies (aPL) occur in approximately $30 \%$ of patients with systemic lupus erythematosus (SLE) and in some patients with no defined connective tissue disease (1). Antiphospholipid antibodies are strongly associated with clinical complications such as arterial and venous thrombosis $(2,3)$, thrombocytopenia $(1,4)$ and recurrent spontaneous abortions $(5,6)$. The presence of aPL in patient sera in association with these complications has been denoted since 1986 as the antiphospholipid syndrome (APS) (7). Other clinical features, such as stroke, pulmonary emboli, livedo reticularis, myocardial infarction and cardiac valve lesions, and Coomb's-positive hemolytic anemia, were later included in the APS syndrome (811). APS is now defined as the presence of any of the above complications in association with aPL detected by either ELISA or lupus anticoagulant tests $(8,11)$. Cardiolipin, a component of the inner mitochondrial membrane, is the common phospholipid used to detect aPL, also known as anticardiolipin antibodies (aCL) (1). APS may occur in the setting of SLE or other collagen vascular diseases (namely secondary APS) or in the absence of these disorders, being commonly known as primary APS (or PAPS) (10-12).

The report of APS and its clinical complications has led to increased interest in the origin and properties of aPL. Here we present the clinical manifestations of APS and review the origin of aPL based on experimentally 
established aPL characteristics. Within this context, we discuss the most probable pathogenic consequences induced by these antibodies.

\section{Antiphospholipid antibodies and clinical associations}

\section{Thrombosis}

The most evident clinical manifestations of APS are thrombosis or thromboembolic vascular occlusions. Veins and arteries of all sizes and in any location may be involved. Thrombosis is usually recurrent and may be confined to a single location; however, some patients have thrombosis in both the arterial and venous circulation. Deep vein thromboses in the lower extremities are very common and may be complicated by pulmonary thromboembolism (13-15). Venous thrombosis may manifest as Budd-Chiari syndrome (16), hepatomegaly, pancreatitis, nephrotic syndrome (secondary to renal vein thrombosis (17)), Addison's disease (18), pulmonary embolism, pulmonary hypertension, or retinal vein thrombosis (19).

\section{Thrombocytopenia and hemolytic anemia}

Thrombocytopenia in SLE is strongly associated with aPL $(1,20-23)$. The IgG isotype of aPL has been detected in $72 \%$ of SLE patients with thrombocytopenia. Interestingly, $31 \%$ of 96 patients with chronic idiopathic autoimmune thrombocytopenia presented higher levels of aCL (21). In APS patients, thrombocytopenia is usually mild $\left(>50,000\right.$ platelets $\left./ \mathrm{mm}^{3}\right)$ and may be associated with Coomb's positive hemolytic anemia (Evans' syndrome) (21-22).

\section{Cardiac complications}

APS patients may present ischemia or infarction of the left or occasionally right ventricle, secondary to coronary artery throm- bosis (24). Hemodynamically significant valve lesions, vegetations, or pseudotumors (thought to result from endocardial thrombosis) have also been reported (25).

\section{Recurrent spontaneous abortion}

Recurrent spontaneous abortion is a major and frequent complication of APS (26). Women with SLE and aPL have a rate of fetal death up to six times higher when compared with healthy women $(27,28)$. Moreover, among women with high levels of aPL, a history of prior fetal losses appears to compound the risk for further fetal demise. Increased awareness of this syndrome prompted a number of studies evaluating aPL in women with a history of recurrent fetal demise but with no known connective tissue disease $(29,30)$. aPL levels were elevated in $13 \%$ to $42 \%$ of women with recurrent (usually three or more) miscarriages. Fetal death during the second or third trimester is more specific for aPL-associated fetal loss, but first-trimester spontaneous abortion is not uncommon. It was reported that $8 \%$ of women with first-trimester recurrent spontaneous abortions were aCL-positive $(5,6)$. Placental insufficiency due to thrombosis is believed to cause fetal growth retardation, fetal demise, and preterm labor. There have been reports of thrombosis occurring in neonates of mothers with APS $(31,32)$. However, the risk of these children developing APS is very small, and the major long-term complications appear to be secondary to low birth weight $(33,34)$.

\section{Neurological complications}

Arterial thrombosis in patients with aPL often involves the cerebrovascular circulation and is expressed as stroke or transient ischemic attacks. Recurrent or chronic cerebral ischemia may manifest as intellectual/ cognitive deterioration and dementia (35). Patients are often young, with the mean age 
of patients with aPL and cerebrovascular ischemia being under 50 years (13). Thromboses of both small and large arteries as well as veins have been reported. The limited cerebrovascular histopathological data in both primary and secondary APS suggest a disturbance of microvascular coagulation with deposition of fibrin thrombi in small to medium-sized vessels (36), and only rarely has true cerebral vasculitis been documented (37). In some patients with aPL, cardiac emboli are a possible cause of cerebrovascular disease, perhaps contributing to large vessel thrombosis $(25,35,36)$. The risk of recurrent stroke or transient ischemic attack is markedly increased in patients with aPL who have already had their first stroke. In a retrospective study of stroke in young patients, aPL positivity was associated with an eight-fold higher risk of recurrence (38). Multi-infarct dementia has been reported in APS patients (39), and the triad of recurrent strokes, livedo reticularis, and dementia (Sneddon's syndrome) has been associated with aPL (40). Ocular ischemia in APS encompasses ischemic optic neuropathy, retinal artery occlusion, combined retinal artery and vein occlusion and amaurosis fugax (41). In 1985, a woman with transverse myelitis, aPL, and a lupus-like disorder was reported (42). Transverse myelitis is an uncommon manifestation of SLE, occurring in approximately $1 \%$ of patients. Twelve such SLE patients had aPL, and six had thrombocytopenia, thrombosis, livedo reticularis, leg ulcers, and other clinical findings of APS. The pathophysiology of spinal cord damage in these patients is unknown, but ischemia or direct interaction of aPL with CNS phospholipids has been suggested (43). Several studies suggest an association between aPL and Guillain-Barré syndrome, seizures, chorea (44) and migraine headaches (45).

\section{Cutaneous lesions}

Livedo reticularis and other thrombotic skin lesions are recognized features of APS (46). Other cutaneous manifestations of APS include pyoderma-like leg ulcers, digital gangrene, and widespread cutaneous necrosis (47).

\section{Renal involvement}

In addition to renal vein thrombosis, accompanied by massive proteinuria, smallvessel non-vasculitic thrombi (thrombotic microangiopathy) may also occur in the kidneys of some APS patients (18).

\section{Antiphospholipid detection}

In 1906, Wassermann (48) described aPL as a serological marker for syphilis. In 1941, Pangborn (49) isolated and identified the antigenic component from bovine heart extracts as cardiolipin (diphosphatidylglycerol). Cardiolipin is a phospholipid unique to biomembranes which have coupled phosphorylation and electron-transport, i.e., mitochondria, chloroplasts, chomatophores, and bacterial plasma membranes (50). Cardiolipin, together with lecithin and cholesterol, is used as the antigen in a serodiagnostic flocculation test for syphilis referred to as the VDRL (Venereal Disease Research Laboratory) test. When specific tests for treponemal antibodies, such as the Treponema pallidum immobilization test, were developed (51), it became clear that not all individuals with a positive Wassermann or VDRL reaction had syphilis. The term "biological false-positive serological test for syphilis" (BFP-STS) was then introduced. Moore and Mohr (52) identified two distinct groups of patients: one with transient BFP-STS reactions, usually associated with viral or other infections, and the other whith BFP-STS results persisting for a period of six months or more (termed chronic BFP-STS). The latter had a high prevalence of autoimmune disorders such as SLE, Sjögren's syndrome, autoimmune hemolytic anemia, Hashimoto's thyroiditis, 
and rheumatoid arthritis (53).

A report of two patients with hemorrhagic disorders and prolonged prothrombin times as well as BFP-STS prompted speculation about the relationship between BFPSTS and a circulating lupus anticoagulant (LA), identified in the gamma globulin fraction of patient sera (54). Though LA was originally associated with bleeding, later work showed that this association is rare and that, paradoxically, LA is more often associated with thrombosis $(2,3)$. LA competes for phospholipids with other coagulation factors. Adequate testing for LA requires freshly prepared platelet-depleted plasma and therefore cannot be performed on stored serum or inadequately prepared plasma. Dissatisfaction with the lack of sensitivity of the VDRL test and difficulties in measuring LA increased together with clinical awareness of the association between antiphospholipid antibodies and thrombosis, thrombocytopenia, and recurrent spontaneous abortions. These facts led investigators to devise a simple and reliable technique for detecting and characterizing aPL. In 1983, Harris et al. (1) designed a radioimmunoassay using cardiolipin as antigen, later converted to an enzyme-linked immunoassay (ELISA) (55). Standard calibrators (samples with defined international units) for $\operatorname{IgG}, \operatorname{IgM}$, and IgA aPL have been established, allowing interlaboratory comparison of results (55). Although aPL and LA can be separated by affinity chromatography or cardiolipin liposome adsorption (56), whether aPL and LA share a similar epitope or are completely different antibodies is not known.

\section{Characteristics of antiphospholipid antibodies}

Antiphospholipid antibodies are usually autoimmune or infection-induced; less frequently aPL may be drug-induced $(57,58)$ or occur in patients with lymphoproliferative disorders. The association of non-autoim- mune aPL with clinical complications remains controversial. Research has been focused on both types of aPL (autoimmune and infectious) in an attempt to gain a better understanding of their pathogenicity. Differences in aPL isotype (59), IgG subclass (60), light chain distribution (61), antibody avidity $(60,61)$, phospholipid specificity (62), and cofactor requirement (63-65) for autoimmune and infectious aPL have been identified and are detailed below.

The clinical complications are strongly associated with aPL of the IgG isotype (59,6668). However, in the absence of IgG aPL, IgA and IgM aPL also appear to be associated with clinical complications. In a retrospective study of 40 APS patients, 36 (90\%) were found to have IgG aPL (alone or with other isotypes), while the remaining four had complications associated with IgA and IgM alone (59). Post-infectious aPL are usually low-titer (when detected by ELISA), with the exception of syphilis, when hightiter IgG aPL may occur (61). The IgG subclass of autoimmune aPL may reflect the nature of the antigen that triggers pathogenicity. Among autoimmune aPL, IgG2 is predominant $(61,69)$, while IgG1 and IgG3 are the most common subtypes of anti-DNA, anti-nuclear protein antibodies, and of other autoantibodies $(58,70,71)$. Interestingly, the predominant IgG subclasses for syphilitic aPL are IgG1 and IgG3. The light chain type of autoimmune aPL is predominantly lambda $(61,69)$, while the normal light chain distribution is approximately two-thirds kappa and one-third lambda. The primary light chain of other autoantibodies and syphilitic aPL is kappa (61).

Avidity of aPL for phospholipids, when compared with other antibodies to protein antigens, is generally low. As an illustration, aPL-phospholipid complexes dissociate in the presence of $1 \mathrm{M}$ salt $(56,72)$. aPL purification is still not a standard procedure, partly because the principal epitope recognized by aPL remains uncertain. Therefore, avidity 
measurements are usually presented for a specific aPL isotype. Autoimmune aPL appear to have higher avidity for negatively charged phospholipids than do syphilitic aPL when ELISA-based methods are used (61).

While designing the aPLELISA, investigators noticed that the use of whole bovine serum as test sample diluent reduced background values and enhanced antibody binding to cardiolipin-coated plates. This suggested the presence of a cofactor for aPL in bovine serum that was later identified as $\beta_{2-}$ glycoprotein I ( $\left.\beta_{2} \mathrm{GPI}\right)$, also known as apolipoprotein $\mathrm{H}(64,65)$. Human $\beta_{2}$ GPI is a glycosylated, proline-rich polypeptide composed of 326 amino acids with multiple disulfide bridges. These bridges divide the protein into five short consensus repeats known as 'sushi' domains (73), the last of which is thought to be most important in binding negatively charged macromolecules such as heparin, DNA, and negatively charged phospholipids $(64,65)$. Although the physiologic role of $\beta_{2} \mathrm{GPI}$ is unclear, $\beta_{2} \mathrm{GPI}$ may function as a natural regulator of coagulation by its anticoagulant properties, including inhibition of the contact system of blood coagulation (74) and inhibition of the intrinsic pathway and adenosine diphosphate (ADP)-induced platelet aggregation (74-76). Autoimmune and drug-induced IgG and IgM aPL require $\beta_{2}$ GPI for binding to phospholipids (PL). In contrast, the PL binding of aPL associated with syphilis, HIV, or other infection-induced antibodies is inhibited by $\beta_{2}$ GPI $(63,77)$. This divergence in the phospholipid binding by autoimmune and infectious aPL supports the proposal of a different origin for these two groups of aPL $(61,78)$. Although the degree of enhancement by $\beta_{2}$ GPI may vary (68), autoimmune IgM aPL require lower levels of cofactor than do IgG aPL (79). These findings incited the ongoing controversy regarding the target epitopes recognized by autoimmune aPL. PL modified by $\beta_{2}$ GPI, PL complexed with $\beta_{2}$ GPI (78), and a cryptic epitope on $\beta_{2}$ GPI (or other native proteins) that is exposed when this cofactor binds to cardiolipin (80) are discussed as the target epitope for aPL. Regardless of the identity of the target epitope, the conventional aPL ELISA is the most reliable method of detecting autoimmune aPL for clinical diagnosis. This method uses anionic PL-coated plates and provides sufficient bovine $\beta_{2}$ GPI in the diluent ( $10 \%$ bovine serum). Furthermore, test sera at 1:50 dilution provide an additional $4 \mathrm{mg} / \mathrm{ml}$ of human $\beta_{2}$ GPI for the assay, enough cofactor for the PL-binding and aPL detection (68).

Although the ELISA test is widely used for investigating the phospholipid-binding properties of aPL, the form adopted by the phospholipids in the ELISA plates is unknown. Soluble microparticles or cell fragments are the most probable phospholipid target epitope for aPL circulating in vivo. For studies in solution, unilamellar liposomes, in which the phospholipids are organized in bilayers, have been adopted as a biomimetic model (81). Using electron paramagnetic resonance, it was demonstrated that purified IgG aPL from SLE or APS patients and from syphilis patients induce superficial membrane defects (in the polar head group region) in liposomes composed by different molar ratios of cardiolipin and phosphatidylcholine. Another distinct aPL property was reported with this technique: autoimmune aPL, but not infectious aPL, induce packing lipid defects in the core of the bilayer (82). $\beta_{2}$ GPI-free IgG aPL from autoimmune and infectious diseases, shown to bind to cardiolipin in the absence of $\beta_{2}$ GPI in a modified ELISA (83), induced the leakage of the internal contents of these liposomes, detected by carboxyfluorescein fluorescence $(82,84,85)$. Purified native and recombinant human $\beta_{2}$ GPI itself induced the leakage of the liposomes in a temperature- and concentration-dependent manner (86). In this liposome model, $\beta_{2}$ GPI presented the cofactor effect inducing a synergistic increase in the leakage rate induced by autoimmune IgG 
aPL $(84,86)$. $\beta_{2}$ GPI requirement for the maximum leakage rate was inversely related to IgG aPL affinity for cardiolipin (86). As expected, $\beta_{2}$ GPI inhibited the leakage from the liposomes induced by infectious IgG aPL (85). These findings suggest that the epitope recognized by autoimmune aPL can be the phospholipid itself or most likely the complex of $\beta_{2}$ GPI-phospholipid. Besides, the inhibition data strongly indicate that $\beta_{2}$ GPI is not part of the epitope recognized by aPL detected in syphilis patients. Altogether, these conclusions show that aPL from autoimmune and infectious diseases are originated by different induction mechanisms, a fact that may explain the divergence in the association of the clinical manifestations (specific for aPL from autoimmune disorders).

\section{Pathogenicity of antiphospholipid antibodies}

The close association of autoimmune aPL with clinical complications such as thrombosis and spontaneous abortion suggests a pathogenic role for these antibodies but does not prove that aPL cause these complications. More convincing evidence that aPL are not merely epiphenomena or surrogates for the true causes of thrombosis comes from experimental models of APS.

APS has been passively transferred by injection of pregnant $B A L B / c$ mice with purified IgG from patients with aPL-associated recurrent spontaneous abortions $(87,88)$. The induction of aPL in mice and rabbits by immunization with foreign (human) $\beta_{2}$ GPI has been reported $(89,90)$. Induction of aPL in young (two to four months) PL/J mice by this method resulted in intrauterine fetal death as well as neurological complications resembling transverse myelopathy (91).

The mechanisms by which aPL may cause thrombosis are unclear, but several have been suggested, such as alteration of the eicosanoid balance (92), interaction of the aPL with the protein C-protein S pathway (93), inhibition of the anti-thrombin III activation (94), activation of platelets (95) and endothelial cells by aPL $(96,97)$ and finally, the interference of aPL with the anticoagulant functions of natural inhibitors of coagulation such as $\beta_{2}$ GPI and placental anticoagulant protein I (also known as annexin V) (98-100). These mechanisms have been elucidated recently (101).

\section{Origin of antiphospholipid antibodies}

It seems likely that autoimmune aPL are produced during antigen-driven immune responses in subjects with a particular genetic background. The precise nature of the inciting antigens and the major genes involved are unknown. Pure phospholipids are not immunogenic, and immunization of laboratory animals with phospholipid plus adjuvant does not induce aPL. Immunization of mice or rabbits with purified, lipid-free, heterologous $\beta_{2}$ GPI, a phospholipid-binding protein, induces aPL with properties similar to autoimmune aPL $(89,102)$. We believe that foreign $\beta_{2}$ GPI binds PL in vivo, thus forming an immunogenic complex against which antibodies are produced. To test this hypothesis and to determine whether the presence of intact $\beta_{2}$ GPI is required, we immunized mice with a synthetic pentadecapeptide that spans Gly 274-Cys 288 in the fifth domain of human $\beta_{2}$ GPI and contains the putative PL binding site (103). Immunization with this peptide (which we have termed "GDKV" conjugated to carrier proteins (BSA or KLH), but not the peptide alone, induced aPL production in two normal (NIH/Swiss and PL/J) strains of mice (104). These studies suggest that the natural stimulus for autoimmune aPL may be a foreign protein (e.g., a viral or bacterial product) with PL-binding properties similar to those of $\beta_{2}$ GPI or the GDKV-BSA conjugates.

Further studies are necessary to answer 
the various remaining questions about aPL. The research about the origin of aPL is directed not only at the identification of the pathogenic mechanisms that lead to the clinical manifestations, but mainly at the development of better treatments for SLE and APS patients.

\section{References}

1. Harris EN, Gharavi AE, Boey ML, Patel MB, Mackworth-Young CG, Loizou S \& Hughes GRV (1983). Anticardiolipin antibodies: detection by radioimmunoassay and association with thrombosis in systemic lupus erythematosus. Lancet, ii: 1211-1213.

2. Bowie WEJ, Thompson JH, Pascuzzi CA \& Owen CA (1963). Thrombosis in systemic lupus erythematosus despite circulating anticoagulants. Journal of Clinical Investigation, 62: 416-430.

3. Boey ML, Colaco CB, Gharavi AE, Elkon KB, Loizou S \& Hughes GRV (1983). Thrombosis in systemic lupus erythematosus: striking association with the presence of circulating lupus anticoagulant. British Medical Journal, 287: 1021-1023.

4. Harris EN, Chang JK, Asherson RA, Aber VR, Gharavi AE \& Hughes GRV (1986). Thrombosis, recurrent fetal loss and thrombocytopenia: predictive value of the anticardiolipin test. Archives of Internal Medicine, 146: 2153-2156.

5. Lockshin MD, Druzin M, Goei S, Qamar T, Magid M, Janovic L \& Ferenc M (1985). Antibody to cardiolipin as a predictor to fetal death in pregnant patients with systemic lupus erythematosus. New England Journal of Medicine, 313: 152-156.

6. Lockshin MD, Qamar T \& Levy RA (1990). Anticardiolipin and related antibodies: thrombosis and fetal death. In: Scott JS \& Bird HA (Editors), Pregnancy, Autoimmunity and Connective Disorders. Oxford University Press, New York, 185-211.

7. Hughes GRV, Harris EN \& Gharavi AE (1986). The antiphospholipid syndrome. Journal of Rheumatology, 13: 486-489.

8. Lockshin MD (1994). Antiphospholipid antibody syndrome. Rheumatic Diseases Clinics of North America, 20: 45-59.

9. Sammaritano LR \& Gharavi AE (1992). Antiphospholipid syndrome. Clinical and Laboratory Medicine, 12: 41-59.

10. Asherson RA (1988). A primary antiphospholipid syndrome? Journal of Rheumatology, 15: 1742-1746.

\section{Acknowledgments}

We are grateful to Dr. Hernan Chaimovich, $\mathrm{PhD}$, for fruitful discussions and revisions.
11. Alarcón-Segovia D \& Sanchez-Guerrero J (1989). Primary antiphospholipid syndrome. Journal of Rheumatology, 16: 482488.

12. Vianna JL, Khamashta MA, Ordi-Ros J, Font J, Cervera R, Lopezsoto A, Tolosa C, Franx J, Sebva A, Ingelmo M, Vilurdell M \& Hughes GRV (1994). Comparison of the primary and secondary antiphospholipid syndrome: a European multi central study of 114 patients. American Journal of Medicine, 96: 3-9.

13. Harris EN, Gharavi AE, Asherson RA, Khamashta MA \& Hughes GRV (1994). Antiphospholipid antibodies: middle aged but robust. Journal of Rheumatology, 21: 978-981.

14. Asherson RA, Khamashta MA, Ordi-Ros $J$, Derksen RHWM, Machin SJ, Barquinero J, Out HH, Harris EN, VilardellTorress M \& Hughes GRV (1989). The 'primary' antiphospholipid syndrome: major clinical and serological features. Medicine, 68: 366-374.

15. Asherson RA, Mackworth-Young CG, Boey ML, Hull RG, Saunders A, Gharavi AE \& Hughes GRV (1983). Pulmonary hypertension in systemic lupus erythematosus. British Medical Journal, 287: 10241025.

16. Asherson RA, Hackett D, Gharavi AE, Harris EN, Kennedy $H G$ \& Hughes GRV (1986). Pulmonary hypertension in systemic lupus erythematosus: a report of three cases. Journal of Rheumatology, 13: 416-420.

17. Mackworth-Young CG, Loizou S \& Walport MJ (1989). Primary antiphospholipid syndrome: features of patients with raised anticardiolipin antibodies and no other disorders. Annals of the Rheumatic Diseases, 48: 362-367.

18. Asherson RA, Lanham JG, Hull RG, Boey ML, Gharavi AE \& Hughes GRV (1984). Renal vein thrombosis in systemic lupus erythematosus: association with the 'lupus anticoagulant'. Clinical Experimental Rheumatology, 2: 75-79.
19. Rao RH, Vagnucci AH \& Amico JA (1989). Bilateral massive adrenal haemorrhage: early recognition and treatment. Annals of Internal Medicine, 110: 227-235.

20. Harris EN, Asherson RA, Gharavi AE, Morgan SH, Derue E \& Hughes GRV (1985). Thrombocytopenia in SLE and related autoimmune disorders: association with anticardiolipin antibody. British Journal of Haematology, 59: 227-230.

21. Koike T, Sueishi M, Funaki H, Tomioka H \& Yoshida S (1984). Antiphospholipid antibodies and biological false positive serological test for syphilis in patients with systemic lupus erythematosus. Clinical and Experimental Immunology, 56: 193-199.

22. Deleze M, Oria CV \& Alarcón-Segovia D (1988). Occurrence of both hemolytic anemia and thrombocytopenia purpura (Evan's syndrome) in systemic lupus erythematosus. Relationship to antiphospholipid antibodies. Journal of Rheumatology, 15: 611-615.

23. Harris EN, Gharavi AE \& Hedge U (1985). Anticardiolipin antibodies in autoimmune thrombocytopenia purpura. British Journal of Haematology, 59: 231-234.

24. Rallings $P$, Exner T \& Abraham R (1989). Coronary artery vasculitis and myocardial infarction associated with antiphospholipid antibodies in a pregnant woman. Australian New Zealand Journal of Medicine, 19: 347-350.

25. Chartash EK, Lans DM, Paget SA, Qamar T \& Lockshin MD (1989). Aortic insufficiency and mitral regurgitation in patients with systemic lupus erythematosus and the antiphospholipid syndrome. American Journal of Medicine, 86: 406-412.

26. Reece EA, Gabrielli S, Cullen MT, Zheng XC, Hobbins JC \& Harris EN (1990). Recurrent adverse pregnancy outcome and antiphospholipid antibodies. American Journal of Obstetrics and Gynecology, 163: 162-169.

27. Branch DW, Scott JR, Kochenour NK \& Hershgold E (1985). Obstetric complications associated with the lupus antico- 
agulant. New England Journal of Medicine, 313: 1322-1326.

28. Lubbe WF \& Liggins GC (1985). Lupus anticoagulant and pregnancy. American Journal of Obstetrics and Gynecology, 153: 322-327.

29. Cowchock S, Smith JB \& Gocial B (1986). Antibodies to phospholipids and nuclear antigens in patients with repeated abortions. American Journal of Obstetrics and Gynecology, 155: 1002-1010.

30. Barbui T, Cortelazzo S, Galli M, Parazzini F, Rossi E, Finazzi G \& Radici E (1988). Antiphospholipid antibodies in early repeated abortions: a case-controlled study. Fertility and Sterility, 50: 589-592.

31. Nachman RL \& Silverstein R (1993). Hypercoagulable states. Annals of Internal Medicine, 119: 819-827.

32. Tabbutt S, Griswold WR, Ogino MT, Mendozo AE, Allen JB \& Reznik VM (1994). Multiple thromboses in a prenatal infant associated with maternal phospholipid antibody syndrome. Journal of Perinatology, XIV: 66-70.

33. Labarrere CA, Catoggio LJ, Mullen EG \& Althabe $\mathrm{OH}$ (1986). Placental lesions in maternal autoimmune diseases. American Journal of Reproductive Immunology and Microbiology, 12: 78-87.

34. Hanly JG, Gladman DD, Rose TH, Laskin CA \& Urowitz MB (1988). Lupus pregnancy: a prospective study of placental changes. Arthritis and Rheumatism, 31: 358-366.

35. Asherson RA, Mercey D, Phillips G, Sheehan N, Gharavi AE, Harris EN \& Hughes GRV (1987). Recurrent stroke and multi-infarct dementia in systemic lupus erythematosus: association with antiphospholipid antibodies. Annals of the Rheumatic Diseases, 46: 605-611.

36. Alarcón-Segovia D, Cardiel MH \& Reyes E (1989). Antiphospholipid arterial vasculopathy. Journal of Rheumatology, 16: 762767.

37. Brey RL, Hart RG, Sherman DG \& Tegeler $\mathrm{CH}$ (1990). Antiphospholipid antibodies and cerebral ischemia in young people. Neurology, 40: 1190-1196.

38. Woodard C, Brey RL \& Hart RG (1991). Neuropathological findings in stroke associated with antiphospholipid antibodies. Neurology, 41: 296 (Abstract).

39. Coull BM \& Goodnight SH (1990). Antiphospholipid antibodies, prethrombotic state and stroke. Stroke, 21: 1370-1374.

40. Levine SR, Langer SL, Albers JW \& Welch KM (1988). Sneddon's syndrome: an antiphospholipid antibody syndrome? Neurology, 38: 789-800.
41. Tolosa-Vilella C, Ordi-Ros J, JordanaComajuncosa R, Selva-O'Callaghan A \& Vilardell-Tarres M (1990). Occlusive ocular vascular disease and antiphospholipid antibodies. Annals of the Rheumatic Diseases, 49: 203 (Letter).

42. Harris EN, Gharavi AE, Mackworth-Young CG, Patel BM, Derue G \& Hughes GRV (1985). Lupoid sclerosis: a possible pathogenetic role for antiphospholipid antibodies. Annals of the Rheumatic Diseases, 44: $281-283$

43. Lavalle C, Pizaro S, Drenkard C, SanchezGuerrero J \& Alarcón-Segovia D (1990). Transverse myelitis: a manifestation of systemic lupus erythematosus strongly associated with antiphospholipid antibodies. Journal of Rheumatology, 17: 34-37.

44. Asherson RA, Derkson RH, Harris EN, Bouma BN, Gharavi AE, Kater L \& Hughes GRV (1987). Chorea in systemic lupus erythematosus and 'lupus-like' disease: association with antiphospholipid antibodies. Seminars in Arthritis and Rheumatism, 16: 253-259.

45. Briley DP, Coull BM \& Goodnight SH (1989). Neurological disease associated with antiphospholipid antibodies. Annals of Neurology, 25: 221-227.

46. Weinstein $\mathrm{C}$, Miller $\mathrm{MH}$, Axtens $\mathrm{R}$, Buchanan R \& Littlejohn GO (1987). Livedo reticularis associated with increased titers of anticardiolipin antibodies in systemic lupus erythematosus. Archives of Dermatology, 123: 596-600.

47. Grobb JJ \& Bonerandi JJ (1989). Thrombotic skin disease as a marker of the anticardiolipin syndrome: livedo vasculitis and distal gangrene associated with abnormal serum antiphospholipid activity. Journal of the American Academy of Dermatology, 20: 1063-1069.

48. Wassermann A, Neisser A \& Bruck C (1906). Eine serodiagnostiche Reaction bei Syphilis. Deutsche Medizinische Wochenschrift, 32: 745-489.

49. Pangborn MC (1941). A new serologically active phospholipid from beef heart. Proceedings of the Society for Experimental Biology and Medicine, 48: 484-486.

50. Hoch FL (1992). Cardiolipin and biomembrane function. Biochimica et Biophysica Acta, 1113: 71-133.

51. Nelson RA \& Mayer MM (1949). Immobilization of Treponema pallidum in vitro by antibody produced in syphilitic infection. Journal of Experimental Medicine, 89: 369-374.

52. Moore JE \& Mohr CF (1952). Biologically false-positive tests for syphilis: type, incidence, and cause. Journal of the Ameri- can Medical Association, 150: 467-473.

53. Tan E, Cohn AS, Fries JF, Masi AT, McShane DJ, Rothfield NF, Schaller JG, Talal N \& Winchester RJ (1982). The revised criteria for the classification of systemic lupus erythematosus. Arthritis and Rheumatism, 25: 1271-1277.

54. Laurell AB \& Nilsson IM (1957). Hypergammaglobulinemia, circulating anticoagulant, and biological false-positive Wassermann reaction: a study of two cases. Journal of Laboratory and Clinical Medicine, 49: 694-707.

55. Harris EN, Gharavi AE, Patel BM \& Hughes GRV (1987). Evaluation of the anticardiolipin antibody test: report of an international workshop held 4 April 1986. Clinical and Experimental Immunology, 68: 215-222.

56. Exner T, Sahman N \& Trudinger B (1988) Separation of anticardiolipin antibodies from lupus anticoagulant on a phospholipid-coated polystyrene column. Biochemical and Biophysical Research Communications, 155: 1001-1007.

57. Canoso RT \& Sise HS (1982). Chlorpromazine induced lupus anticoagulant and associated immunologic abnormalities. American Journal of Hematology, 13: 121 129

58. Rubin RL, Tang FL, Chan EK, Pollard KM Tsay G \& Tan EM (1986). IgG subclasses of autoantibodies in systemic lupus erythematosus, Sjögren's syndrome, and drug-induced autoimmunity. Journal of Immunology, 137: 2528-2534.

59. Gharavi AE, Harris EN, Asherson RA \& Hughes GRV (1987). Antiphospholipid antibodies: isotype distribution and phospholipid specificity. Annals of the Rheumatic Diseases, 46: 1-6.

60. Costello PB \& Green FA (1988). Binding affinity of serum immunoglobulin $G$ to cardiolipin and other phospholipids in patients with systemic lupus erythematosus and syphilis. Infection and Immunity, 56: 1738-1742.

61. Levy RA, Gharavi AE, Sammaritano LR, Habina L, Qamar T \& Lockshin MD (1990). Characteristics of $\lg G$ antiphospholipid antibodies in patients with systemic lupus erythematosus and syphilis. Journal of Rheumatology, 17: 1036-1041.

62. Harris EN, Gharavi AE, Wasley GD \& Hughes GRV (1988). Use of an enzymelinked immunosorbent assay and of inhibition studies to distinguish between antibodies to cardiolipin from patients with syphilis or autoimmune disorders. Journal of Infectious Diseases, 157: 23-31.

63. Matsuura E, Igarashi $\mathrm{Y}$, Fujimoto $\mathrm{M}$, 
Ichikawa K \& Koike T (1990). Anticardiolipin cofactor(s) and differential diagnosis of autoimmune diseases. Lancet, 336: 177-178.

64. Galli M, Comfurius $\mathrm{P}$, Maassen HC, Hemker HC, de Baets MH, van BredaVriesman PJ, Barburi T, Zwaal RF \& Bevers EM (1990). Anticardiolipin antibodies (ACA) directed not to cardiolipin but to a plasma protein cofactor. Lancet, 335 : 1544-1547.

65. McNeil HP, Simpson RJ, Chesterman CN \& Krillis SA (1990). Anti-phospholipid antibodies are directed against a complex antigen that includes a lipid binding inhibitor of coagulation: beta 2 -glycoprotein I (apolipoprotein $\mathrm{H}$ ). Proceedings of the National Academy of Sciences, USA, 87: 41204124.

66. Alving BM, Barr CF \& Tang DB (1990). Correlation between lupus anticoagulants and anticardiolipin antibodies in patients with prolonged activated partial thromboplastin time. American Journal of Medicine, 88: 112-116.

67. Lockshin MD, Druzin ML \& Qamar $T$ (1989). Prednisone does not prevent recurrent fetal death in women with antiphospholipid antibody. American Journal of Obstetrics and Gynecology, 160: 439443.

68. Sammaritano LR, Lockshin MD \& Gharavi AE (1992). Antiphospholipid antibodies differ in aPL cofactor requirement. Lupus, 1: 83-90.

69. Tsutsumi A, Koike T, Ichikawa K, Schemata K, Takabayashi K, Tomioka H \& Yoshida S (1988). IgG subclass distribution of anticardiolipin antibody in patients with systemic lupus erythematosus. Journal of Rheumatology, 15: 1764-1767.

70. Schur PH, Monroe M \& Rothfield N (1972). The subclass of antinuclear and antinucleic acid antibodies. Arthritis and Rheumatism, 15: 174-182.

71. Bonfa E, Llovet R \& Elkon KB (1988). Immunoblot analysis of IgG subclasses of multiple lupus antibodies. Journal of $I \mathrm{~m}$ munology, 140: 2231-2236.

72. Harris EN, Gharavi AE, Tincani A, Chan JK, Englert $H$, Mantelli $P$, Allegro $F$, Ballestrieri G \& Hughes GRV (1985). Affinity purified anti-cardiolipin and anti-DNA antibodies. Journal of Clinical and Laboratory Immunology, 17: 155-162.

73. Lozier J, Takahashi N \& Putnam FW (1984). Complete amino acid sequence of human $B_{2}$-glycoprotein I. Proceedings of the National Academy of Sciences, USA, 81: 3640-3644.

74. Schousboe I (1985). B2-glycoprotein I: a plasma inhibitor of the contact activation of the intrinsic blood coagulation pathway. Blood, 66: 1086-1091.

75. Nimpf J, Wurm H \& Kostner GM (1987). Beta-2-glycoprotein I (apo-H) inhibits the release reaction of human platelets during ADP-induced aggregation. Atherosclerosis, 63: 109-114.

76. Nimpf J, Bevers E, Bomans P, Till U, Wurm H, Kostner GM \& Zwaal RF (1986). Prothrombinase activity of human platelets is inhibited by $B_{2}$-glycoprotein I. Biochimica et Biophysica Acta, 884: 142-149.

77. Hunt JE, McNeil HP, Morgan GJ, Crameri RM \& Krillis SA (1992). A phospholipid- $\beta_{2}-$ glycoprotein-I complex is the antigen for anticardiolipin antibodies in autoimmune disease but not infections. Lupus, 1: 8390.

78. Pierangeli SS, Harris EN, Davis SA \& DeLorenzo G (1992). B2-glycoprotein I $\left(B_{2} \mathrm{GPI}\right)$ enhances cardiolipin binding activity but is not the antigen for antiphospholipid antibodies. British Journal of Haematology, 82: 565-570.

79. Roubey RAS (1994). Autoantibodies to phospholipid-binding plasma proteins: a new view of lupus anticoagulants and other "antiphospholipid" autoantibodies. Blood, 84: 2854-2867.

80. Gharavi AE (1992). Antiphospholipid cofactor. Stroke, 23 (Suppl 1): 7-10.

81. Gremião MPD, Celli CM \& Chaimovich H (1996). Anticardiolipin antibodies from syphilis and systemic lupus erythematosus induce leakage in cardiolipin-phosphatidylcholine vesicles. Brazilian Journal of Medical and Biological Research, 29: 489494.

82. Celli $\mathrm{CM}$, Gremião MPD, Bianconi ML \& Chaimovich H (1996). Antiphospholipid antibodies from systemic lupus erythematosus and syphilis patients cause different effects on cardiolipin-containing vesicles. Lupus, 5: 544 (Abstract).

83. Cucurull E, Celli CM, Gharavi EE, Tang H, Ordi-Ros J, Espinoza LR \& Gharavi AE (1997). Binding of antiphospholipid antibodies from autoimmune diseases to cardiolipin in the absence of $B_{2}$-glycoprotein I. Journal of Investigative Medicine, 45: 23 (Abstract).

84. Celli $\mathrm{CM}$, Tang $\mathrm{H}$, Chaimovich $\mathrm{H}$ \& Gharavi AE (1996). Antiphospholipid antibodies and $B_{2}$-glycoprotein I induce leakage of the contents of cardiolipin-containing vesicles. Arthritis and Rheumatism, 39 (Suppl): S96 (Abstract).

85. Celli CM, Gharavi EE, Tang $\mathrm{H}$, Chaimovich H, Espinoza LR \& Gharavi AE (1997). Effect of $B_{2}$-glycoprotein I on the interaction of cardiolipin vesicles with antiphospholipid antibodies from autoimmune and infectious diseases. Journal of Investigative Medicine, 45: 48 (Abstract).

86. Gharavi EE, Celli CM, Tang H, Espinoza LR \& Gharavi AE (1997). Induction of antiphospholipid antibodies in mice by recombinant human $B_{2}$-glycoprotein I cloned in yeast. Journal of Investigative Medicine, 45: 48 (Abstract).

87. Branch DW, Dudley DJ, Mitchell MD, Greighton KA, Abbott TM, Hammond EH \& Baynes RA (1990). Immunoglobulin G fractions from patients with antiphospholipid antibodies cause fetal death in Balb/c mice: a model for autoimmune fetal loss. American Journal of Obstetrics and Gynecology, 163: 210-216.

88. Blank M, Cohen J \& Shoenfeld Y (1991). Induction of antiphospholipid syndrome in naive mice with mouse lupus monoclonal and human polyclonal anti-cardiolipin antibodies. Proceedings of the $\mathrm{Na}$ tional Academy of Sciences, USA, 88: 3069-3073.

89. Gharavi $A E$, Sammaritano LR, Wen J \& Elkon KB (1992). Induction of antiphospholipid autoantibodies by immunization with $B_{2}$-glycoprotein I (apolipoprotein $\mathrm{H}$ ). Journal of Clinical Investigation, 90: 11051109.

90. Gharavi AE \& Aron AL (1994). Experimental models for antiphospholipid studies. Haemostasis, 24: 204-207.

91. Garcia CO, Kanbour-Shakir A, Tang H, Moline JF, Esinoza LR \& Gharavi AE (1997). Induction of experimental antiphospholipid syndrome in PL/J mice following immunization with $\mathrm{B}_{2} \mathrm{GPI}$. American Journal of Reproductive Immunology, 37: 118-124.

92. Schorer AE, Duane PG, Woods VL \& Niewoehner DE (1992). Some antiphospholipid antibodies inhibit phospholipase $\mathrm{A}_{2}$ activity. Journal of Laboratory and Clinical Medicine, 120: 67-77.

93. Ruiz-Argüelles A, Vasquez-Prado J, Deleze M, Perez-Romano B, Drenkard C, Alarcón-Segovia D \& Ruiz-Argüelles JM (1993). Presence of serum antibodies to coagulation protein $C$ in patients with systemic lupus erythematosus is not associated with antigenic or functional protein $\mathrm{C}$ deficiencies. American Journal of Hematology, 44: 58-59.

94. Shabita S, Harpel PC, Gharavi AE, Rand J \& Fillit $H$ (1994). Autoantibodies to heparin from patients with antiphospholipid antibody syndrome inhibit formation of antithrombin III-thrombin complexes. Blood, 83: 2532-2540. 
95. Bevers EM, Smeets EF, Comfurius P \& Zwaal RFA (1996). Regulatory mechanisms in maintenance and modulation of transmembrane lipid asymmetry: pathophysiological implications. Lupus, 5: 480-487.

96. Baguley E \& Hughes GRV (1989). Antiendothelial cell antibodies. Journal of Rheumatology, 16: 716-717.

97. Vermylen J \& Arnout $J$ (1992). Is the antiphospholipid syndrome caused by antibodies direct against physiologically relevant phospholipid-protein complexes? Journal of Laboratory and Clinical Medicine, 120: 10-12.

98. Sammaritano LR, Gharavi AE, Soberano C, Levy RA \& Lockshin MD (1992). Phospholipid binding of antiphospholipid antibodies and placental anticoagulant protein. Journal of Clinical Immunology, 12: 27-35.
99. Pierangeli SS, Dean J, Gharavi AE, Goldsmith GH, Branch DW \& Harris EN. (1996). Studies on the interaction of placental anticoagulant protein I (PAP I), B2glycoprotein I (B2 GPI) and antiphospholipid (aPL) antibodies in the prothrombinase reaction and in solid phase anticardiolipin assays. Journal of Laboratory and Clinical Medicine, 128: 194-201.

100. Rand JH, Wu XX, Guller S, Gil J, Guha A, Scher J \& Lockwood CJ (1994). Reduction of annexin- $V$ (placental anti-coagulant protein I) on placental villi of women with antiphospholipid antibodies and recurrent spontaneous abortion. American Journal of Obstetrics and Gynecology, 171: 1566-1572.

101. Triplett DA (1995). Antiphospholipid-protein antibodies: laboratory detection and clinical relevance. Thrombosis Research, 78: 1-31.

102. Gharavi AE, Sammaritano LR, Bovastro JL \& Wilson WA (1995). Specificities and characteristics of B2-glycoprotein I-induced antiphospholipid antibodies. Journal of Laboratory and Clinical Medicine, 125: 775-778.

103. Hunt J \& Krilis S (1994). The fifth domain of $B_{2}$-glycoprotein I contains a phospholipid binding site (Cys281-Cys288) and a region recognized by anticardiolipin antibodies. Journal of Immunology, 152: 653-659.

104. Gharavi $A E$, Tang $H$, Gharavi EE, Wilson WA \& Espinoza LR (1994). Induction of aPL by immunization with a 5 -amino acid peptide. Arthritis and Rheumatism, 38: S296 (Abstract). 